\title{
A Review on Synthesis of Silver Nanoparticles and their Biomedical Applications
}

\author{
Bhabani Shankar Panda ${ }^{1, *}$ \\ 1 Department of Chemistry, Ravenshaw University, Cuttack, Odisha, India \\ * Correspondence: bpanda607@ gmail.com (B.S.P.);
}

Scopus Author ID 0205578499

Received: 21.03.2021; Revised: 6.05.2021; Accepted: 9.06.2021; Published: 27.06.2021

\begin{abstract}
The silver (Ag) metal is considered a very useful metal for treating consume wound diseases, open wounds, and cuts, respectively. Nowadays, nanotechnology has created a surprising effect by changing over metallic silver into silver nanoparticles (AgNPs) for better applications. However, according to advanced technology, the synthesis of nanoparticles occurs by using organic or biological techniques rather than physical and chemical techniques. Also, the synthesis of silver nanoparticles (AgNPs) using biological or organic sources is cost-effective and eco-friendly. Silver nanoparticles (AgNPs) are broadly used as antibacterial specialists, helping us cure novel diseases and questionable sicknesses. In biomedicine, silver nanoparticles have huge points of interest because of their physical and synthetic flexibility. The uses of silver nanoparticles (AgNPs) in nano-gels, nano-fluids, silverbased coating over food and medical devices are advancing. Still, there is a need to innovate a better version of silver nanoparticles for vigorous use in an eco-friendly way. So, this review describes the methods of synthesis, activities under various conditions, and different biomedical uses of silver nanoparticles (AgNPs) in detail.
\end{abstract}

Keywords: silver nanoparticles (AgNPs); larvicidal activity; anti-inflammation; microscopic organisms.

(C) 2021 by the authors. This article is an open-access article distributed under the terms and conditions of the Creative Commons Attribution (CC BY) license (https://creativecommons.org/licenses/by/4.0/).

\section{Introduction}

Nanotechnology is a quickly developing science technique with very useful roles to human beings, animals, and the environment. Nanoparticles (NPs) are amazing discoveries of nanotechnology to settle the current world's issues. Among the different metallic and nonmetallic NPs, silver nanoparticles (AgNPs) have been extensively investigated for their relevance and flexibility [1-6]. The AgNPs have established wide consideration in the fields of wastewater treatment, biomedicine, drug delivery, vector control and agriculture [7, 8-16]. The effective conductivity of AgNPs has amplified their applications in a wide array of products such as electronic devices, inks, gums, pastes and in controlling microbial growth and infections, which has likewise also made them eco-accommodating [17-19].

The physical and synthetic blend of AgNPs has pulled in different biophysical and compound applications attributable to amalgamation's immaculateness. However, both of these syntheses consume high-energy chemicals and are often contaminated with toxic chemicals [20-22]. In this way, the combination of AgNPs utilizing bio-sensible diminishing specialists, such as plants, microorganisms, parasites, and green growth, has prompted green nanofabrication [23]. 
Biosynthesis of nanoparticles as an arising feature of the convergence of nanotechnology and biotechnology has expanded consideration because of the developing need to grow ecologically amiable innovations in nanomaterial blend [24]. The naturally incorporated NPs are known to have incredible antimicrobial, antimalarial, antiviral and antiparasitic exercises. In a few investigations, bacteria such as Shewanella oneidensis and Lacto-bacillus sp., etc., have been used to synthesize of AgNPs [25,26]. In previous reports, [27] plant extracts have been used to develop sustainable and eco-friendly approaches for AgNPs synthesis. AgNPs synthesized using plant extracts as reducing agents have also shown effective antibacterial activities against clinical pathogens [23]. Nonetheless, notwithstanding the developing advances in the union of AgNPs, organic sources have consistently portrayed huge possibilities for creating expected AgNPs. Be that as it may, moderate endeavors have been made to popularize organically blended AgNPs for public use. Accordingly, the ebb and flow audit stress the likely biomedical utilization of the organically integrated AgNPs in addressing a wide exhibit of infections and infections.

\section{Synthesis of Nanoparticles (NPs)}

Nanomaterials are classified as non-metallic and inorganic $\left(\mathrm{SiO}_{2}, \mathrm{TiO}_{2}, \mathrm{ZnO}_{2}, \mathrm{Fe}_{2} \mathrm{O}_{3}\right.$, $\mathrm{CeO}_{2}, \mathrm{ZrO}_{2}, \mathrm{Cu}_{2} \mathrm{O}$ ), metallic and metal alloys ( $\mathrm{Au}, \mathrm{Ag}, \mathrm{Pd}, \mathrm{Cu}, \mathrm{Fe}, \mathrm{Ni}, \mathrm{Co}, \mathrm{Mn}, \mathrm{Mg}$ ), carbonbased nanomaterials (fullerenes, carbon nanotubes, graphene), dendrimers and nano-polymers (polymeric nanotubes and NPs, nanowires, nanorods, nanocellulose, polymer films) and quantum dots (cadmium telluride, cadmium selenide, quantum dots free cadmium) $[4,21,28,29]$. Nanomaterials are generated either by natural, substance, or actual techniques. Among the various NPs, AgNPs have been generally abused for biomedical applications. Ag nanoparticle combination is performed through two methodologies specifically, start to finish and base to top methodology [30]. In the top to bottom approach, bulk materials are used for NPs synthesis, while in the bottom-to-top approach, NPs are synthesized based on the packaging of atoms, molecules, or clusters [31]. There are various methods employed to synthesize AgNPs; they are classified based on the sources and reducing agents used for the conversion of nano-Ag. The physicochemical methods used to synthesize AgNPs include chemical reduction, gamma-ray radiations, microwave, electrochemical, and laser ablation $[32,33]$. However, certain restrictions associated with the physical and substance techniques make the organic strategy prevalent for AgNPs amalgamation. Both genuinely and chemically integrated AgNPs have short lives up to 20 min, buildup items are framed as side-effects during amalgamation, sweet-smelling amines are delivered, the cycle of union is exorbitant, it consumes high force, and longtime upkeep is required.

The biological synthesis of AgNPs involves major living resources or organisms. The significant sources utilized for the amalgamation of AgNPs are microscopic organisms, growths, green growth, and plants. During the amalgamation of AgNPs utilizing natural sources, the living organic entities reduce specialists or balance out specialists or covering specialists and decrease $\mathrm{Ag}^{+}$to create $\mathrm{Ag}^{0}$ [34,28]. Plants or plant extracts are effortlessly safe, accessible, and non-toxic concentrates containing many metabolites for the synthesis of AgNPs. However, compared to bacteria, fungi produce higher concentrations of AgNPs due to the high contents of extracellular secondary metabolites used as capping and reducing agents during synthesis. In this way, considering the downsides of physical and substance strategies, an organic technique for synthesizing AgNPs is viewed as a conceivably more secure, nonpoisonous, and savvy course. 


\section{Applications}

Although AgNPs are utilized in an assortment of uses, including thin films [35,36], surface coatings [37], batteries [38], energy harvesting [39], and conductors [40], clinical applications have pulled in extraordinary most consideration because of expanding perilous illnesses worldwide and multidrug opposition challenges in vague medication conveyance. Inappropriately, the economic status for the utilization of AgNPs is literally limited. However, the flexibility of AgNPs on a wide scope of contaminations is very much appreciated. Significantly, AgNPs serve as effective antimicrobial agents by moving the proteins and enzymes of the host/pathogenic cells and ultimately cause cell death. The antibacterial impacts of AgNPs are probably going to be exhibited through the particles, which transform into $\mathrm{Ag}^{+}$ particles and create receptive oxygen species. They are also liable to upset the development flagging pathway inside the bacterial cells by tweaking the tyrosine phosphorylation of proteins significant for cell practicality [41]. Silver most likely assumes a functioning part in restraining bacterial development by restricting covalently to the cell surfaces and, in the long run, disturbing the cell films [42-46]. The joined antimicrobial specialist upsets the cell layers of the bacterial cells by physical and ionic wonders. Unthinkingly, Ag+ particles have been reported to cooperate with the thiol gatherings of compounds and proteins in the films and cytoplasm's that are significant for bacterial breath and the transportation of different substances across the layers. Furthermore, silver particles are notable for being viable in forestalling the diseases of wounds [47,48].

Also, AgNPs directed by functionalizing the surfaces and formed with antimicrobials were viable. Recently, AgNPs were circulated in the polymer lattice [20] for reasonable reactivity. An enormous number of studies have utilized AgNPs for their different biomedical properties, for example, insecticidal, antilarval, antibiofilm, and anticancer properties [28,4952]. Definitely, this audit could help the peruses to configuration research works and comprehend the adequacy of AgNPs alongside expanded investigations. Schematic portrayal and the table would empower an exhaustive comprehension of different parts of AgNPs in the clinical applications.

\subsection{Antimicrobial activity of AgNPs.}

AgNPs AgNPs are natural antimicrobial specialists and their inhibitory impacts on microbes. For example, Staphylococcus aureus, Escherichia coli, and yeasts, were accounted for AgNPs have critical focal points in the pharmacological business to fix different bacterial and viral dis-facilitates [53]. Specifically, AgNPs target clinical microbes, which incorporate multidrug safe (MDR) and broadened range beta-lactamase (ESBL) microorganisms [20]. AgNPs were found to have higher antibacterial exercises than silver in that capacity, which could be credited to the existence of wide surface regions of AgNPs and more divisions in their surface particles [54]. The previously mentioned highlights of AgNPs would encourage the NPs to enter just into the bacterial cells and initiate cell passing. Also, the section of AgNPs into the bacterial cells causes DNA harm and adjusts their capacities. The limiting of $\mathrm{Ag}^{+}$particles and the sulfur incorpo-appraised proteins cause the breakdown of the bacterial cell dividers and upset the protein union component [55]. In addition, AgNPs advance the creation of responsive oxygen species (ROS, for example, hydrogen peroxide and subsequently cause pathogenic microorganism's restraint [56]. AgNPs delivered utilizing the growth Fusarium oxysporum indicated antibacterial action. The NPs consolidated garments can be utilized in clinics to limit the danger of diseases because of Staphylococcus aureus [57,58]. Table 1 shows the antibacterial exercises of AgNPs orchestrated utilizing various life 
forms against various pathogenic microscopic organisms. Furthermore, the size, shape, and surface charge of AgNPs assume indispensable parts in antibacterial exercises. AgNPs, with the same surface regions yet with unique shapes, display contrasts in antibacterial exercises. Shortened three-sided silver nanoplates have shown the most grounded antibacterial exercises due to their huge surface zone to volume proportions and gem structures [59]. Besides, decidedly charged AgNPs showed expanded inhibitory consequences for gram-negative microscopic organisms, notwithstanding their opposition levels when contrasted with gram-positive microorganisms [28].

\subsection{Larvicidal activity of AgNPs}

Larviciding is a naturally protected technique to control and slaughter mosquito hatchlings or pupae in water. In recent years, mosquito hatchlings are viewed as significant dangers because of improved protection from existing medications. Then, phytoextracts were additionally utilized as biocontrol specialists against mosquitoes. In such a manner, the biosynthesized AgNPs are considered biocontrol specialists because of their solid efficacies and eco-friendly natures. AgNPs from different plant extracts, such as Feronia elephantum [60], Azadirachta indica [61], Agave sisalana [62], Eclipta prostrate [53], Ficus racemosa [63] and Sterculia foetida $L$. [64] have been found to possess larvicidal activities against different stages of larvae of Culex quinquefasciatus, Aedes aegypti and Anopheles stephensi. AgNPs synthesized from the mangrove plant Rhizophora mucronata were found to have lethal effects on the fourth instar larvae of Aedes aegypti and Culex quinquefasciatus [65]. A prolonged mosquito repellence was achieved by the large droplets of nanoemulsion with low release rates as compared to the small droplet nanoemulsions [66,67]. Another study reported that the AgNPs synthesized from the Belosynapsis kewensis leaf extract had inhibited the fourth instar of Anopheles stephensi and Aedes aegypti. AgNPs synthesized using the isoamyl acetate extract of Annona squamosa were found to exhibit mosquito larvicidal activities against dengue and filariasis vectors, such as Aedes aegypti and Culex quinquefasciatus [51]. The spherical-shaped Ag NPs integrated utilizing Eupatorium odoratum leaf remove indicated larvicidal efficacies against the third and fourth instar hatchlings of Culex quinquefasciatus [68]. Subsequently, AgNPs accomplish larvicidal action by the denaturation of the sulfur-containing proteins, or phosphorous-containing intensifies like the DNA present in the cell dividers. This indicated the route to cell organelles' corruption and, finally, cell brokenness and cell demise [69]. Karthiga et al. proved to have effective larvicidal activity against Aedes aegypti for AgNPs synthesis takes place using Garcinia mangostana bark extract [70]. Holarrhena antidysenterica(L.) bark's aqueous extract showed larvicidal activity against the third instar larvae of Aedes aegypti L. And Culex quinquefasciatus [71]. AgNPs synthesized with the help of Sargassum polycystum showed high transience of about $80 \%$ and $90 \%$ after $48 \mathrm{hr}$ and $72 \mathrm{hr}$ treatment against Ae.aegypti and almost $80 \%$ Cx. quinquefasciatus larvae were killed after $72 \mathrm{hr}$ treatment [72].

Silver applies to the slaughter of organisms and parasites utilizing various instruments, such as interruption of cell dividers, inactivation of cell digestion systems, and harming hereditary materials [73,74]. A couple of works have detailed the antimalarial movement of silver and its metal edifices until now. Synthetically combined silver (I) protoporphyrin IX indicated antimalarial movement under in vitro conditions against a CQ-delicate FCR-3 strain [75]. Mono and bis(N-heterocyclic-carbene) (NHC)- based ligands advanced murdering activities against the chloroquine-safe strain of $P$. falciparum [76]. Although artificially combined 
AgNPs are proficient, their poisonousness remaining parts a worry. In this manner, organic sources are being abused for the blend of AgNPs. Natural sources give a reasonable and ecofriendly stage for the combination of AgNPs and advance compelling antimalarial activities. Rajakumar and Rahuman reported that AgNPs were synthesized using the aqueous extract of Eclipta prostrate and were tested against the larvae of the filariasis vector, Culex quinquefasciatus say and the malarial vector, Anopheles subpictus Grassi (Diptera: Culicidae) [77]. The blended AgNPs demonstrated LC50 = 27.49 and $4.56 \mathrm{mg} / \mathrm{L} ; \mathrm{LC} 90=70.38$ and 13.14 $\mathrm{mg} / \mathrm{L}$, individually against C. quinquefasciatus and $\mathrm{LC}_{50}=27.85$ and $5.14 \mathrm{mg} / \mathrm{L} ; \mathrm{LC}_{90}=71.45$ and $25.68 \mathrm{mg} / \mathrm{L}$, respectively against A. subpictus. AgNPs synthesized using the leaves of Catharanthus roseus showed anti-plasmodial activity against Plasmodium falciparum [78]. AgNPs synthesized using the aqueous extract of Cocus nucifera showed effective antilarvicidal activity against the larvae of Anopheles stephensi and C. quinquefasciatus [79]. AgNPs synthesized using $\beta$-caryophyllene isolated from the leaf extract of Murraya koenigii showed potential toxicity towards chloroquine-sensitive Plasmodium falciparum (IC50: $2.34 \pm$ $0.07 \mu \mathrm{g} / \mathrm{mL}$ ). Recently, it has been proved that the AgNPs synthesized from the leaf extracts of Leucas aspera and Hyptis suaveolens possessed promising larvicidal activities against malarial, dengue and filariasis vectors. Hence, the mosquitocidal and larvicidal exercises of AgNPs integrated utilizing a substance and natural techniques indicated the effectiveness of AgNPs to kill the danger of intestinal sickness and malaria-related infections [80]. Further, the focal point of scientists ought to be on lessening the harmfulness of AgNPs, which will advance their applications in the climate in a more secure and eco-friendly way.

Table 1. Silver nanoparticles and their antimicrobial activities.

\begin{tabular}{l|l|c}
\multicolumn{1}{c}{$\begin{array}{c}\text { Organisms used for AgNPs } \\
\text { Synthesis }\end{array}$} & \multicolumn{1}{c}{ Pathogenic Bacteria } \\
\hline Fungus Alternaria sp. & $\begin{array}{l}\text { Bacillus subtilis, Staphylococcus aureus, Escherichia coli } \text { and } \\
\text { Serratia marcescens }\end{array}$ & [81] \\
\hline Actinobacteria Streptacidiphilus & Pseudomonas aeruginosa, Staphylococcus aureus and Proteus & [82] \\
durhamensis & mirabilis & [83] \\
\hline Lysinibacillus varians & Candida albicans and Candida glabrata & [85] \\
\hline Root extract of Helicteres isora & Bacillus subtilis and Micrococcus luteus & [86] \\
\hline Bacterium Ochrobactrum anhtropi & Salmonella typhi, Salmonella paratyphi, Vibrio cholerae and & \\
\hline Fruit Dimocarpus Longan Lour. & Staphylococcus aureus & \\
peel & &
\end{tabular}

\subsection{Insecticidal Activity of AgNPs.}

Insects and illnesses on food creating and business crops are significant dangers to farming. Creepy crawlies which rely upon plants for food are called bothers. Vermin harms youthful leaves; foods are grown from the ground. Expanded utilization of synthetic insect sprays may make unfavorable and extreme outcomes to the biological systems, for example, influencing human wellbeing [87], loss of biodiversity, loss of nitrogen obsession [88], and obliteration of environments [89]. As of late, nano-pesticide plans have been recommended for crop nuisance and infection administrations. Accordingly, there is a more prominent favorable position in utilizing biosynthesized silver and lead nanoparticles [90,91] because they are effectively realistic, safe (not cancer-causing) and hold various metabolites [92,93]. Euphorbia prostrate watery leaf separate intervened AgNPs have insecticidal movement against Sitophilus oryzae bother, which for the most part influences rice, wheat and maize grains [94]. Insecticidal exercises of AgNPs and sulfur nanoparticles (S NPs) from various sources on larval, pupal and 
grown-ups of the organic product fly Drosophila melanogaster [95] were accounted. Even though both the NPs showed insecticidal exercises, the AgNPs incorporated from olive and mulberry exhibited high mortality and a considerable decline in larval longevity.

\subsection{Antibiofilm Activity of AgNPs}

Thickly pressed microbial cell networks structure self-blended polymeric lattices on biotic or abiotic surfaces, known as biofilms [96]. Biofilm development is considered the superb method of life for microorganisms because most of the world's biomass is set up in a biofilm state and organisms are profoundly lenient to exogenous pressure [97]. Biofilms of pathogenic microscopic organisms cause huge clinical diseases. The utilization of NPs for the advancement of antibiofilm specialists is very much reported [98]. The antibiofilm activities of various biosynthesized NPs were studied using clinically important pathogenic bacteria such as Klebsiella pneumoniae. Electrostatic communications of NPs with the bacterial layers cause disturbance of the films. NPs can enter profound into the developed biofilm due to their high surface-to-volume proportions. Biosynthesized gold and AgNPs have been accounted for to uncover antibiofilm exercises at lower fixations [99-101]. $0.2 \mu \mathrm{g} / \mathrm{mL}$ of AgNPs synthesized using the fungus Aspergillus flavus effectively reduced the formation of Escherichia coli and Pseudomonas aeruginosa biofilms up to $70 \%$. In a similar manner, $4 \mu \mathrm{g} / \mathrm{mL}$ of Emericella nidulans mediated AgNPs inhibited more than 50\% biofilm formation \% in Staphylococcus aureus and Pseudomonas aeruginosa [100]. Absolute inhibition of Klebsiella pneumoniae and Staphylococcus aureus biofilms was achieved with a trivial amount $(0.0596 \mu \mathrm{g} / \mathrm{mL}$ and 0.0683 $\mu \mathrm{g} / \mathrm{mL}$, respectively) of AgNPs synthesized using the plant Zingiber officinale [102]. Another examination demonstrated that $0.2 \mathrm{mM}$ convergence of AuNPs blended utilizing a bacteriophage repressed $80 \%$ of biofilm form in Pseudomonas aeruginosa.

\subsection{Anticancer Activity of Silver Nanoparticles.}

Currently, there are a few anticancer medications on the lookout for restorative alternatives and to oversee malignancy mortality; however, significant results and fundamental harmfulness has been accounted for [103]. Examining disease is a fascinating subject regarding nanomedicine's field for finding new restorative, anticancer materials to overcome dangerous tumors [104-108]. Nanobiotechnology intervened cancer treatments have high specificities as they are less obtrusive $[109,110]$.

Table 2. Role of bio-synthesized AgNPs in anti-inflammation

\begin{tabular}{l|l|l|c}
\multicolumn{1}{c|}{$\begin{array}{c}\text { Organisms used for AgNPs } \\
\text { Synthesis }\end{array}$} & \multicolumn{1}{|c|}{ Constituents as Stabilizing Agents } & $\begin{array}{l}\text { Production of Anti- } \\
\text { inflammatory Agents }\end{array}$ & References \\
\hline $\begin{array}{l}\text { Terminalia sp. (T. bentazoe, } \\
\begin{array}{l}\text { T. bellerica, } \text { T. mellueri } \text { and } \\
\text { Terminalia catapa) leaves }\end{array}\end{array}$ & $\begin{array}{l}\text { Polysaccharides, protein, polyphenolic and } \\
\text { flavonoid compounds }\end{array}$ & $\begin{array}{l}\text { Reactive oxygen species } \\
\text { (ROS) }\end{array}$ & {$[116]$} \\
\hline $\begin{array}{l}\text { Leaf extract of Pteris tripartita Sw } \\
\text { Phenolics, flavonoids, terpenoids, tannins, } \\
\text { proteins and glycosides }\end{array}$ & $\begin{array}{l}\text { Histamine, serotonin, and } \\
\text { prostaglandins }\end{array}$ & {$[117]$} \\
\hline $\begin{array}{l}\text { Plant Leucas aspera } \text { (willd.), } \\
\text { Abutilon indicum }\end{array}$ & $\begin{array}{l}\text { Terpenoids, alkaloids, flavonoids, phenol, } \\
\text { tannins, phytosterols, carbohydrates, } \\
\text { aromatics, aldehydes, alkenes, aromatics, alkyl } \\
\text { halides, aliphatic amines, amines, alkyl halides }\end{array}$ & Indomethacin & {$[118]$} \\
\hline
\end{tabular}

Curiously, metallic NPs address an alluring stage for potential disease diagnostics and treatment because of their interesting, appropriate ties for high infiltration and target particularity for diagnostics and therapeutics, separately [111-113]. Also, the metallic NPs 
could likewise be formed into natural compartments, including peptides, monoclonal antibodies, DNA/RNA, and additionally tumor markers to explicitly target cell surface proteins or receptors on disease cells $[114,115]$.

\subsection{Anti-inflammatory Activity of AgNPs.}

The reaction of the immune system against contaminations and harm to body cells is known as inflammation. It works for the disposal of illegal factors and helps get sorted out the tissues and reestablish the cells' elements [119]. Disappointment in this intricate cycle can prompt the improvement of various fiery disorders [120]. A calming reaction is an interaction of the production of safe, responsive mixtures, for example, interleukins and cytokinins by keratinocytes [121]. In spite of the fact that the endocrine framework secretes certain fiery arbiters, for example, catalysts and antibodies, other forthcoming mitigating specialists, including cytokines, IL-1, IL-2 are emitted by the essential insusceptible organs. These calming middle people prompt the recuperating interaction [3]. Bio-combined gold and platinum NPs accomplished positive injury mending and tissue recovery [122]. Certain AgNPs which have calming exercises are introduced in Table 2. AgNPs synthesized from plants were found to animate the creation of cytokines because the alkaloids or flavonoids present in the plants would go about as covering specialists, hence giving extra pharmacological properties [120]. Higher dosages of nanosilver have been reported to accomplish a solid creation of Th1cells followed by the emission of fiery cytokines IL-2, INF- $\gamma$, which assume an indispensable part in cell insusceptibility [123]. AgNPs covered by the alkaloids of the unripe products of Flautist nigrum improved the calming action in human fringe blood mononuclear cells [120]. In addition, the AgNPs synthesized from plants, such as Pteris tripartite [117], Acalypha indica, Garcinia mangostana [123], Centratherum punctatum Cass, Rosa damascene [95], and Abutilon indicum [122], exhibited anti-inflammatory activities.

\section{Conclusions}

This review gives a complete investigation of the general and attentive biomedical uses of AgNPs. These have been used as surface covering agents or thin films in emergency clinics for many decades. Silver has shown predictable applications against microbes to cells specifically. The physicochemical characteristics of silver nanoparticles like adherence, shape, size and SPR make them appropriate to target pathogenic microorganisms to tainted mammalian cells. The developing threat of multidrug-safe microbes (MDR) to resist antibiotics and other manufactured compounds has redirected more consideration towards NPs. The objective explicit and simple infiltration of AgNPs makes them an appropriate alternative to antibiotics against MDR and ESBL forming bacteria. Apart from pathogenic microbes, silver nanoparticles have conceivably demonstrated to repress or execute illness-causing vectors or agents like insects, mosquito larvae, crustaceans, and biofilm-forming microorganisms. Consequently, the current survey has been focused on providing comprehensive details on the potential and adaptable biomedical uses of AgNPs.

\section{Funding}

This research received no external funding. 


\section{Acknowledgments}

Support from Centurion University of Technology and Management, Odisha, India, and Silicon Institute of Technology, Bhubaneswar, India, are highly acknowledged.

\section{Conflicts of Interest}

The author declares no conflict of interest regarding the publication of this article.

\section{References}

1. Satyavani, K.; Ramanathan, T.; Gurudeeban, S. Green synthesis of silver nanoparticles by using stem derived callus extract of bitter apple (Citrullus colocynthis). Dig J Nanomater Biostruct 2011, 6, 1019-1024.

2. Satyavani K, Gurudeeban S, Ramanathan T, Balasubramanian T. Biomedical potential of silver nanoparticles synthesized from calli cells of Citrullus colocynthis (L.) Schrad. Journal of Nanobiotechnology 2011, 9, 43.

3. Kaliamurthi, S.; Selvaraj, G.; V, D.; Ramanathan. Heliotropium Curassavicum mediated Silver Nanoparticles for Environmental Application. Research Journal of Chemistry and Environment 2013, 17, $27-33$.

4. Behera, M.; Biswal, S.K.; Panda, B. S.; Ahemad, M. A. Study of Optical, Structural, Thermal and Dielectric Properties of Poly (vinylidene diflouride) / Cuprous Oxide Polymer Nano composites, Asian Journal of Chemistry; 2020, 32, 106-110, https://doi.org/10.14233/ajchem.2020.22344.

5. Kaliamurthi, S.; Selvaraj, G.; Çakmak, Z.E.; Çakmak, T. Production and characterization of spherical thermostable silver nanoparticles from Spirulina platensis (Cyanophyceae). Phycologia 2016, 55, 568-576, http://dx.doi.org/10.2216/15-98.1.

6. Panda, B. S. Synthesis and characterizations of cuprous oxide-poly (vinylidene fluoride) polymer nanocomposites, Centurion University of Technology and Management, Bhubaneswar, Odisha, 2019, 1-34.

7. Benelli, G. Plant-mediated biosynthesis of nanoparticles as an emerging tool against mosquitoes of medical and veterinary importance: a review. Parasitol. Res. 2016, 115, 23-34, https://doi.org/10.1007/s00436-0154800-9.

8. Lewis Oscar, F.; Vismaya, S.; Arunkumar, M.; Thajuddin, N.; Dhanasekaran, D.; Nithya, C. Algal nanoparticles: synthesis and biotechnological potentials. In Algae-Organisms for Imminent Biotechnology, IntechOpen: 2016.

9. Hamouda, R.A.; Hussein, M.H.; Abo-elmagd, R.A.; Bawazir, S.S. Synthesis and biological characterization of silver nanoparticles derived from the cyanobacterium Oscillatoria limnetica. Sci. Rep. 2019, 9, 13071, https://doi.org/10.1038/s41598-019-49444-y.

10. Guilger-Casagrande, M.; Lima, R.d. Synthesis of Silver Nanoparticles Mediated by Fungi: A Review. Frontiers in Bioengineering and Biotechnology 2019, 7, 287, https://doi.org/10.3389/fbioe.2019.00287.

11. Yaqoob, A.A.; Umar, K.; Ibrahim, M.N.M. Silver nanoparticles: various methods of synthesis, size affecting factors and their potential applications-a review. Applied Nanoscience 2020, 10, 1369-1378, https://doi.org/10.1007/s13204-020-01318-w.

12. Xu, L.; Wang, Y.-Y.; Huang, J.; Chen, C.-Y.; Wang, Z.-X.; Xie, H. Silver nanoparticles: Synthesis, medical applications and biosafety. Theranostics 2020, 10, 8996-9031, https://doi.org/10.7150/thno.45413.

13. Lee, S.H.; Jun, B.-H. Silver Nanoparticles: Synthesis and Application for Nanomedicine. Int. J. Mol. Sci. 2019, 20, 865, https://doi.org/10.3390/ijms20040865.

14. Liu, T.; Baek, D.R.; Kim, J.S.; Joo, S.-W.; Lim, J.K. Green Synthesis of Silver Nanoparticles with Size Distribution Depending on Reducing Species in Glycerol at Ambient pH and Temperatures. ACS Omega 2020, 5, 16246-16254, https://doi.org/10.1021/acsomega.0c02066.

15. Hamida, R.S.; Abdelmeguid, N.E.; Ali, M.A.; Bin-Meferij, M.M.; Khalil, M.I. Synthesis of silver nanoparticles using a novel cyanobacteria Desertifilum sp. extract: their antibacterial and cytotoxicity effects. International journal of nanomedicine 2020, 15, 49, https://doi.org/10.2147/IJN.S238575.

16. Feroze, N.; Arshad, B.; Younas, M.; Afridi, M.I.; Saqib, S.; Ayaz, A. Fungal mediated synthesis of silver nanoparticles and evaluation of antibacterial activity. Microsc. Res. Tech. 2020, 83, 72-80, https://doi.org/10.1002/jemt.23390.

17. Husen, A.; Siddiqi, K.S. Phytosynthesis of nanoparticles: concept, controversy and application. Nanoscale Research Letters 2014, 9, 229, http://dx.doi.org/10.1186/1556-276X-9-229. 
18. LewisOscar, F.; MubarakAli, D.; Nithya, C.; Priyanka, R.; Gopinath, V.; Alharbi, N.S.; Thajuddin, N. One pot synthesis and anti-biofilm potential of copper nanoparticles (CuNPs) against clinical strains of Pseudomonas aeruginosa. Biofouling 2015, 31, 379-391, https://doi.org/10.1080/08927014.2015.1048686.

19. Chari, N.; Felix, L.; Davoodbasha, M.; Sulaiman Ali, A.; Nooruddin, T. In vitro and in vivo antibiofilm effect of copper nanoparticles against aquaculture pathogens. Biocatalysis and Agricultural Biotechnology 2017, 10, 336-341, https://doi.org/10.1016/j.bcab.2017.04.013.

20. MubarakAli, D.; Arunkumar, J.; Pooja, P.; Subramanian, G.; Thajuddin, N.; Alharbi, N.S. Synthesis and characterization of biocompatibility of tenorite nanoparticles and potential property against biofilm formation. Saudi Pharmaceutical Journal 2015, 23, 421-428, https://doi.org/10.1016/j.jsps.2014.11.007.

21. Behera, M.; Biswal, S.K.; Ahemad, M.A.; Panda, B.S. Demonstration of Enhanced Thermal Stability, Dielectric Constant and Low Tangent Loss by Particle-Reinforced Silver/poly (Vinylidene Difluoride) Polymer Nanocomposites. Biointerface Research in Applied Chemistry 2021,. 11, 12584-12595, https://doi.org/10.33263/BRIAC115.1258412595.

22. Shanmuganathan, R.; MubarakAli, D.; Prabakar, D.; Muthukumar, H.; Thajuddin, N.; Kumar, S.S.; Pugazhendhi, A. An enhancement of antimicrobial efficacy of biogenic and ceftriaxone-conjugated silver nanoparticles: green approach. Environ. Sci. Pollut. Res. Int. 2018, 25, 10362-10370, https://doi.org/10.1007/s11356-017-9367-9.

23. MubarakAli, D.; Thajuddin, N.; Jeganathan, K.; Gunasekaran, M. Plant extract mediated synthesis of silver and gold nanoparticles and its antibacterial activity against clinically isolated pathogens. Colloids Surf. B. Biointerfaces 2011, 85, 360-365, https://doi.org/10.1016/j.colsurfb.2011.03.009.

24. Bhattacharya, D.; Gupta, R.K. Nanotechnology and potential of microorganisms. Crit. Rev. Biotechnol. 2005, 25, 199-204, https://doi.org/10.1080/07388550500361994.

25. Sintubin, L.; De Windt, W.; Dick, J.; Mast, J.; van der Ha, D.; Verstraete, W.; Boon, N. Lactic acid bacteria as reducing and capping agent for the fast and efficient production of silver nanoparticles. Appl. Microbiol. Biotechnol. 2009, 84, 741-749, http://dx.doi.org/10.1007/s00253-009-2032-6.

26. Kumar, V.; Bano, D.; Mohan, S.; Singh, D.K.; Hasan, S.H. Sunlight-induced green synthesis of silver nanoparticles using aqueous leaf extract of Polyalthia longifolia and its antioxidant activity. Mater. Lett. 2016, 181, 371-377, http://dx.doi.org/10.1016/j.matlet.2016.05.097.

27. Kumar, V.; Gundampati, R.K.; Singh, D.K.; Bano, D.; Jagannadham, M.V.; Hasan, S.H. Photoinduced green synthesis of silver nanoparticles with highly effective antibacterial and hydrogen peroxide sensing properties. J. Photochem. Photobiol. B: Biol. 2016, 162, 374-385, http://dx.doi.org/10.1016/j.jphotobiol.2016.06.037.

28. Panda, B.S.; Ahemad, M.A.; Mishra, L.N. Green Synthesized Nanoparticles \& An approach towards Antibacterial \& Antimicrobial activities: A Review, International Journal of ChemTech Research 2021, 14, 16-41, https://doi.org/10.20902/IJCTR.2021.140103.

29. P Pulit-Prociak, J.; Banach, M. Silver nanoparticles-a material of the future...? Open Chemistry 2016, 14, 76-91, http://dx.doi.org/10.1515/chem-2016-0005.

30. Iravani, S.; Korbekandi, H.; Mirmohammadi, S.V.; Zolfaghari, B. Synthesis of silver nanoparticles: chemical, physical and biological methods. Res. Pharm. Sci. 2014, 9, 385-406.

31. Tan, G.L.; Yu, X.F. Capping the Ball-Milled CdSe Nanocrystals for Light Excitation. The Journal of Physical Chemistry C 2009, 113, 8724-8729, http://dx.doi.org/10.1021/jp900670x.

32. Natsuki, J.; Natsuki, T.; Hashimoto, Y. A review of silver nanoparticles: synthesis methods, properties and applications. Int. J. Mater. Sci. Appl 2015, 4, 325-332, http://dx.doi.org/10.11648/j.ijmsa.20150405.17.

33. Abou El-Nour, K.M.M.; Eftaiha, A.a.; Al-Warthan, A.; Ammar, R.A.A. Synthesis and applications of silver nanoparticles. Arabian Journal of Chemistry 2010, 3, 135-140, http://dx.doi.org/10.1016/j.arabjc.2010.04.008.

34. Zewde, B.; Ambaye, A.; Stubbs Iii, J.; Raghavan, D. A review of stabilized silver nanoparticles-synthesis, biological properties, characterization, and potential areas of applications. Nanomed 2016, 4, 1-14.

35. Yeo, C.I.; Choi, J.H.; Kim, J.B.; Lee, J.C.; Lee, Y.T. Spin-coated Ag nanoparticles for enhancing light absorption of thin film a-Si:H solar cells. Opt. Mater. Express 2014, 4, 346-351, http://dx.doi.org/10.1364/OME.4.000346.

36. Panda, B. S. and Ahemad, M. A.; Synthesis of Silver Nanoparticles from Mimusops elengi Extract of Raw Fruits and Characterization of PVA-Silver Polymer Nanocomposite Films, Asian Journal of Chemistry; 2021; Vol. 33 (4), 762-766. https://doi.org/10.14233/ajchem.2021.23074. 
37. Jo, Y.K.; Seo, J.H.; Choi, B.-H.; Kim, B.J.; Shin, H.H.; Hwang, B.H.; Cha, H.J. Surface-Independent Antibacterial Coating Using Silver Nanoparticle-Generating Engineered Mussel Glue. ACS Applied Materials \& Interfaces 2014, 6, 20242-20253, http://dx.doi.org/10.1021/am505784k.

38. Bindumadhavan, K.; Chang, P.-Y.; Doong, R.-a. Silver nanoparticles embedded boron-doped reduced graphene oxide as anode material for high performance lithium ion battery. Electrochim. Acta 2017, 243, 282-290, https://doi.org/10.1016/j.electacta.2017.05.063.

39. Fei Guo, C.; Sun, T.; Cao, F.; Liu, Q.; Ren, Z. Metallic nanostructures for light trapping in energy-harvesting devices. Light: Science \& Applications 2014, 3, e161-e161, https://doi.org/10.1038/lsa.2014.42.

40. Gerardo, C.D.; Cretu, E.; Rohling, R. Fabrication of Circuits on Flexible Substrates Using Conductive SU-8 for Sensing Applications. Sensors 2017, 17, http://dx.doi.org/10.3390/s17061420.

41. Shrivastava, S.; Bera, T.; Roy, A.; Singh, G.; Ramachandrarao, P.; Dash, D. Characterization of enhanced antibacterial effects of novel silver nanoparticles. Nanotechnology 2007, 18, 225103, http://dx.doi.org/10.1088/0957-4484/18/22/225103.

42. Shankar, P.D.; Shobana, S.; Karuppusamy, I.; Pugazhendhi, A.; Ramkumar, V.S.; Arvindnarayan, S.; Kumar, G. A review on the biosynthesis of metallic nanoparticles (gold and silver) using bio-components of microalgae: Formation mechanism and applications. Enzyme Microb. Technol. 2016, 95, 28-44, http://dx.doi.org/10.1016/j.enzmictec.2016.10.015.

43. Saratale, G.D.; Saratale, R.G.; Benelli, G.; Kumar, G.; Pugazhendhi, A.; Kim, D.-S.; Shin, H.-S. Anti-diabetic Potential of Silver Nanoparticles Synthesized with Argyreia nervosa Leaf Extract High Synergistic Antibacterial Activity with Standard Antibiotics Against Foodborne Bacteria. J. Cluster Sci. 2017, 28, 17091727, http://dx.doi.org/10.1007/s10876-017-1179.

44. Mat Yusuf, S.N.A.; Che Mood, C.N.A.; Ahmad, N.H.; Sandai, D.; Lee, C.K.; Lim, V. Optimization of biogenic synthesis of silver nanoparticles from flavonoid-rich Clinacanthus nutans leaf and stem aqueous extracts. Royal Society Open Science 2020; 7: 200065, http://dx.doi.org/10.1098/rsos.200065.

45. Meena, R.K.; Meena, R.; Arya, D.K.; Jadoun, S.; Hada, R.; Kumari, R. Synthesis of Silver Nanoparticles by Phyllanthus emblica Plant Extract and Their Antibacterial Activity. Material Science Research India 2020, 17, 136-145, http://dx.doi.org/10.13005/msri/170206.

46. Madhu, G.; Kumar, A.S.; Nair, S.K. Sunlight-induced honey-mediated green synthesis of silver nanoparticles. AIP Conf. Proc. 2019, 2162, 020101, https://doi.org/10.1063/1.5130311.

47. Wright, J.B.; Lam, K.; Hansen, D.; Burrell, R.E. Efficacy of topical silver against fungal burn wound pathogens. Am. J. Infect. Control 1999, 27, 344-350, http://dx.doi.org/10.1016/S0196-6553(99)70055-6.

48. Percival, S.L.; Bowler, P.G.; Russell, D. Bacterial resistance to silver in wound care. J. Hosp. Infect. 2005, 60, 1-7, https://doi.org/10.1016/j.jhin.2004.11.014.

49. Pugazhendhi, A.; Prabakar, D.; Jacob, J.M.; Karuppusamy, I.; Saratale, R.G. Synthesis and characterization of silver nanoparticles using Gelidium amansii and its antimicrobial property against various pathogenic bacteria. Microb. Pathog. 2018, 114, 41-45, http://dx.doi.org/10.1016/j.micpath.2017.11.013.

50. Velayutham, K.; Ramanibai, R. Larvicidal activity of synthesized silver nanoparticles using isoamyl acetate identified in Annona squamosa leaves against Aedes aegypti and Culex quinquefasciatus. The Journal of Basic \& Applied Zoology 2016, 74, 16-22, http://dx.doi.org/10.1016/j.jobaz.2016.02.002.

51. Khalil, A.T.; Ovais, M.; Ullah, I.; Ali, M.; Shinwari, Z.K.; Maaza, M. Biosynthesis of iron oxide (Fe2O3) nanoparticles via aqueous extracts of Sageretia thea (Osbeck.) and their pharmacognostic properties. Green Chemistry Letters and Reviews 2017, 10, 186-201, http://dx.doi.org/10.1080/17518253.2017.1339831.

52. Ahiwale, S.S.; Bankar, A.V.; Tagunde, S.; Kapadnis, B.P. A Bacteriophage Mediated Gold Nanoparticles Synthesis and Their Anti-biofilm Activity. Indian J. Microbiol. 2017, 57, 188-194, http://dx.doi.org/10.1007/s12088-017-0640-x.

53. Song, J.Y.; Kim, B.S. Biological synthesis of bimetallic Au/Ag nanoparticles using Persimmon (Diopyros kaki) leaf extract. Korean J. Chem. Eng. 2008, 25, 808-811, http://dx.doi.org/10.1007/s11814-008-0133-z.

54. Durán, N.; Marcato, P.D.; Conti, R.D.; Alves, O.L.; Costa, F.; Brocchi, M. Potential use of silver nanoparticles on pathogenic bacteria, their toxicity and possible mechanisms of action. J. Braz. Chem. Soc. 2010, 21, 949-959, http://dx.doi.org/10.1590/S0103-50532010000600002.

55. Sondi, I.; Salopek-Sondi, B. Silver nanoparticles as antimicrobial agent: a case study on E. coli as a model for Gram-negative bacteria. J. Colloid Interface Sci. 2004, 275, 177-182, http://dx.doi.org/10.1016/j.jcis.2004.02.012. 
56. Mohammed, A.E. Green synthesis, antimicrobial and cytotoxic effects of silver nanoparticles mediated by Eucalyptus camaldulensis leaf extract. Asian Pacific Journal of Tropical Biomedicine 2015, 5, 382-386, http://dx.doi.org/10.1016/S2221-1691(15)30373-7.

57. Gade, A.K.; Bonde, P.; Ingle, A.P.; Marcato, P.D.; Durán, N.; Rai, M.K. Exploitation of Aspergillus niger for Synthesis of Silver Nanoparticles. Journal of Biobased Materials and Bioenergy 2008, 2, 243-247, http://dx.doi.org/10.1166/jbmb.2008.401.

58. Carson, L.; Bandara, S.; Joseph, M.; Green, T.; Grady, T.; Osuji, G.; Weerasooriya, A.; Ampim, P.; Woldesenbet, S. Green Synthesis of Silver Nanoparticles with Antimicrobial Properties Using Phyla dulcis Plant Extract. Foodborne Pathog. Dis. 2020, 17, 504-511, http://doi.org/10.1089/fpd.2019.2714.

59. Pal S, Tak YK, Song JM. Does the antibacterial activity of silver nanoparticles depend on the shape of the nanoparticle? A study of the Gram-negative bacterium Escherichia coli. Appl. Environ. Microbiol. 2007, 73, 1712, http://dx.doi.org/10.1128/AEM.02218-06.

60. Veerakumar, K.; Govindarajan, M.; Rajeswary, M.; Muthukumaran, U. Low-cost and eco-friendly green synthesis of silver nanoparticles using Feronia elephantum (Rutaceae) against Culex quinquefasciatus, Anopheles stephensi, and Aedes aegypti (Diptera: Culicidae). Parasitol. Res. 2014, 113, 1775-1785, http://dx.doi.org/10.1007/s00436-014-3823-y.

61. Soni, N.; Prakash, S. Silver nanoparticles: a possibility for malarial and filarial vector control technology. Parasitol. Res. 2014, 113, 4015-4022, http://dx.doi.org/10.1007/s00436-014-4069-4.

62. Nunes, F.C.; Leite, J.A.; Oliveira, L.H.G.; Sousa, P.A.P.S.; Menezes, M.C.; Moraes, J.P.S.; Mascarenhas, S.R.; Braga, V.A. The larvicidal activity of Agave sisalana against L4 larvae of Aedes aegypti is mediated by internal necrosis and inhibition of nitric oxide production. Parasitol. Res. 2015, 114, 543-549, http://dx.doi.org/10.1007/s00436-014-4216-y.

63. Velayutham, K.; Rahuman, A.A.; Rajakumar, G.; Roopan, S.M.; Elango, G.; Kamaraj, C.; Marimuthu, S.; Santhoshkumar, T.; Iyappan, M.; Siva, C. Larvicidal activity of green synthesized silver nanoparticles using bark aqueous extract of Ficus racemosa against Culex quinquefasciatus and Culex gelidus. Asian Pac. J. Trop. Med. 2013, 6, 95-101, http://dx.doi.org/10.1016/S1995-7645(13)60002-4.

64. Rajasekharreddy, P.; Rani, P.U. Biofabrication of Ag nanoparticles using Sterculia foetida L. seed extract and their toxic potential against mosquito vectors and HeLa cancer cells. Materials Science and Engineering: C 2014, 39, 203-212, http://dx.doi.org/10.1016/j.msec.2014.03.003.

65. Gnanadesigan, M.; Anand, M.; Ravikumar, S.; Maruthupandy, M.; Vijayakumar, V.; Selvam, S.; Dhineshkumar, M.; Kumaraguru, A.K. Biosynthesis of silver nanoparticles by using mangrove plant extract and their potential mosquito larvicidal property. Asian Pac. J. Trop. Med. 2011, 4, 799-803, http://dx.doi.org/10.1016/S1995-7645(11)60197-1.

66. Sakulku, U.; Nuchuchua, O.; Uawongyart, N.; Puttipipatkhachorn, S.; Soottitantawat, A.; Ruktanonchai, U. Characterization and mosquito repellent activity of citronella oil nanoemulsion. Int. J. Pharm. 2009, 372, 105-111, http://dx.doi.org/10.1016/j.ijpharm.2008.12.029.

67. Chartarrayawadee, W.; Charoensin, P.; Saenma, J.; Rin, T.; Khamai, P.; Nasomjai, P.; On Too, C. Green synthesis and stabilization of silver nanoparticles using Lysimachia foenum-graecum Hance extract and their antibacterial activity. Green Processing and Synthesis 2020, 9, 107-118, https://doi.org/10.1515/gps-20200012.

68. Elemike, E.E.; Onwudiwe, D.C.; Ekennia, A.C.; Sonde, C.U.; Ehiri, R.C. Green Synthesis of Ag/Ag2O Nanoparticles Using Aqueous Leaf Extract of Eupatorium odoratum and Its Antimicrobial and Mosquito Larvicidal Activities. Molecules 2017, 22, http://dx.doi.org/10.3390/molecules22050674.

69. Sap-Iam, N.; Homklinchan, C.; Larpudomlert, R.; Warisnoicharoen, W.; Sereemaspun, A.; Dubas, S.T. UV irradiation-induced silver nanoparticles as mosquito larvicides. Journal of Applied Sciences 2010, 10, 31323136, http://dx.doi.org/10.3923/jas.2010.3132.3136.

70. Karthiga, P.; Rajeshkumar, S.; Annadurai, G. Mechanism of Larvicidal Activity of Antimicrobial Silver Nanoparticles Synthesized Using Garcinia mangostana Bark Extract. J. Cluster Sci. 2018, 29, 1233-1241, http://dx.doi.org/10.1007/s10876-018-1441-z.

71. Kumar, D.; Kumar, G.; Agrawal, V. Green synthesis of silver nanoparticles using Holarrhena antidysenterica (L.) Wall.bark extract and their larvicidal activity against dengue and filariasis vectors. Parasitol. Res. 2018, 117, 377-389, http://dx.doi.org/10.1007/s00436-017-5711-8.

72. Vinoth, S.; Shankar, S.G.; Gurusaravanan, P.; Janani, B.; Devi, J.K. Anti-larvicidal Activity of Silver Nanoparticles Synthesized from Sargassum polycystum Against Mosquito Vectors. J. Cluster Sci. 2019, 30, 171-180, http://dx.doi.org/10.1007/s10876-018-1473-4. 
73. McDonnell, G.; Russell, A.D. Antiseptics and Disinfectants: Activity, Action, and Resistance. Clin. Microbiol. Rev. 1999, 12, 147, http://dx.doi.org/10.1128/CMR.12.1.147.

74. Youngs, W.J.; Knapp, A.R.; Wagers, P.O.; Tessier, C.A. Nanoparticle encapsulated silver carbene complexes and their antimicrobial and anticancer properties: A perspective. Dalton Transactions 2012, 41, 327-336, http://dx.doi.org/10.1039/C1DT11100K.

75. Begum, K.; Kim, H.-S.; Kumar, V.; Stojiljkovic, I.; Wataya, Y. In vitro antimalarial activity of metalloporphyrins against Plasmodium falciparum. Parasitol. Res. 2003, 90, 221-224, http://dx.doi.org/10.1007/s00436-003-0830-9.

76. Hemmert, C.; Fabié, A.; Fabre, A.; Benoit-Vical, F.; Gornitzka, H. Synthesis, structures, and antimalarial activities of some silver(I), gold(I) and gold(III) complexes involving N-heterocyclic carbene ligands. Eur. J. Med. Chem. 2013, 60, 64-75, http://dx.doi.org/10.1016/j.ejmech.2012.11.038.

77. Rajakumar, G.; Abdul Rahuman, A. Larvicidal activity of synthesized silver nanoparticles using Eclipta prostrata leaf extract against filariasis and malaria vectors. Acta Trop. 2011, 118, 196-203, http://dx.doi.org/10.1016/j.actatropica.2011.03.003.

78. Ponarulselvam, S.; Panneerselvam, C.; Murugan, K.; Aarthi, N.; Kalimuthu, K.; Thangamani, S. Synthesis of silver nanoparticles using leaves of Catharanthus roseus Linn. G. Don and their antiplasmodial activities. Asian Pacific Journal of Tropical Biomedicine 2012, 2, 574-580, http://dx.doi.org/10.1016/S22211691(12)60100-2.

79. Roopan, S.M.; Rohit; Madhumitha, G.; Rahuman, A.A.; Kamaraj, C.; Bharathi, A.; Surendra, T.V. Low-cost and eco-friendly phyto-synthesis of silver nanoparticles using Cocos nucifera coir extract and its larvicidal activity. Industrial Crops and Products 2013, 43, 631-635, http://dx.doi.org/10.1016/j.indcrop.2012.08.013.

80. Oseguera-Galindo, D.O.; Oceguera-Contreras, E.; Pozas-Zepeda, D. Silver nanoparticles synthesis using biomolecules of habanero pepper (Capsicum chinense Jacq.) as a reducing agent. Journal of Nanophotonics 2020, 14, 036012, https://doi.org/10.1117/1.JNP.14.036012.

81. Singh, T.; Jyoti, K.; Patnaik, A.; Singh, A.; Chauhan, R.; Chandel, S.S. Biosynthesis, characterization and antibacterial activity of silver nanoparticles using an endophytic fungal supernatant of Raphanus sativus. Journal of Genetic Engineering and Biotechnology 2017, 15, 31-39, http://dx.doi.org/10.1016/j.jgeb.2017.04.005.

82. Buszewski, B.; Railean-Plugaru, V.; Pomastowski, P.; Rafińska, K.; Szultka-Mlynska, M.; Golinska, P.; Wypij, M.; Laskowski, D.; Dahm, H. Antimicrobial activity of biosilver nanoparticles produced by a novel Streptacidiphilus durhamensis strain. J. Microbiol. Immunol. Infect. 2018, 51, 45-54, https://doi.org/10.1016/j.jmii.2016.03.002.

83. Bhakya, S.; Muthukrishnan, S.; Sukumaran, M.; Muthukumar, M.; Biogenic synthesis of silver nanoparticles and their antioxidant and antibacterial activity. Appl Nanosci.; 2016; 6; 755-66. http://dx.doi.org/10.1007/s13204-015-0473-z.

84. Thomas, R.; Janardhanan, A.; Varghese, R.T.; Soniya, E.V.; Mathew, J.; Radhakrishnan, E.K. Antibacterial properties of silver nanoparticles synthesized by marine Ochrobactrum sp. Braz. J. Microbiol. 2014, 45, 12211227, http://dx.doi.org/10.1590/S1517-83822014000400012.

85. Gavrilescu, M. Fate of Pesticides in the Environment and its Bioremediation. Eng. Life Sci. 2005, 5, 497-526, http://dx.doi.org/10.1002/elsc.200520098.

86. Lin, P.-C.; Lin, H.-J.; Liao, Y.-Y.; Guo, H.-R.; Chen, K.-T. Acute Poisoning with Neonicotinoid Insecticides: A Case Report and Literature Review. Basic Clin. Pharmacol. Toxicol. 2013, 112, 282-286, http://dx.doi.org/10.1111/bcpt.12027.

87. Palmer, W.E.; Bromley, P.T.; Brandenburg, R.L. Wildlife \& pesticides-peanuts. North Carolina Cooperative Extension Service; 2007, 10-11.

88. Palaniappan, P.; Sathishkumar, G.; Sankar, R. Fabrication of nanosilver particles using Cymodocea serrulata and its cytotoxicity effect against human lung cancer A549 cells line. Spectrochimica Acta Part A: Molecular and Biomolecular Spectroscopy 2015, 138, 885-890, http://dx.doi.org/10.1016/j.saa.2014.10.072.

89. Yasur, J.; Usha Rani, P. Lepidopteran insect susceptibility to silver nanoparticles and measurement of changes in their growth, development and physiology. Chemosphere 2015, 124, 92-102, http://dx.doi.org/10.1016/j.chemosphere.2014.11.029.

90. Awwad, A.M.; Salem, N.M. Green synthesis of silver nanoparticles byMulberry LeavesExtract. Nanoscience and Nanotechnology 2012, 2, 125-128, http://dx.doi.org/10.5923/j.nn.20120204.06.

91. Zahir, A.; Bagavan, A.; Kamaraj, D.C.; Elango, G.; Rahuman, A. Efficacy of plant-mediated synthesized silver nanoparticles against Sitophilus oryzae. Journal of Biopesticides 2014, 5, 95-102. 
92. Miquel, S.; Lagrafeuille, R.; Souweine, B.; Forestier, C. Anti-biofilm Activity as a Health Issue. Front. Microbiol. 2016, 7, 592, http://dx.doi.org/10.3389/fmicb.2016.00592.

93. Youssif, K.A.; Haggag, E.G.; Elshamy, A.M.; Rabeh, M.A.; Gabr, N.M.; Seleem, A.; Salem, M.A.; Hussein, A.S.; Krischke, M.; Mueller, M.J.; Abdelmohsen, U.R. Anti-Alzheimer potential, metabolomic profiling and molecular docking of green synthesized silver nanoparticles of Lampranthus coccineus and Malephora lutea aqueous extracts. PLoS One 2019, 14, e0223781, https://doi.org/10.1371/journal.pone.0223781.

94. Baelo, A.; Levato, R.; Julián, E.; Crespo, A.; Astola, J.; Gavaldà, J.; Engel, E.; Mateos-Timoneda, M.A.; Torrents, E. Disassembling bacterial extracellular matrix with DNase-coated nanoparticles to enhance antibiotic delivery in biofilm infections. J. Controlled Release 2015, 209, 150-158, http://dx.doi.org/10.1016/j.jconrel.2015.04.028.

95. Araj S-EA, Salem NM, Ghabeish IH, Awwad AM. Toxicity of nanoparticles against Drosophila melanogaster (Diptera: Drosophilidae). Journal of Nanomaterials 2015, 2015, 758132 , http://dx.doi.org/10.1155/2015/758132.

96. Nithya, B.; Jayachitra, A. Improved antibacterial and antibiofilm activity of plant mediated gold nanoparticles using Garcinia cambogia. Int. J. Pure App. Biosci 2016, 4, 201-210, http://dx.doi.org/10.18782/23207051.2238 .

97. Barapatre, A.; Aadil, K.R.; Jha, H. Synergistic antibacterial and antibiofilm activity of silver nanoparticles biosynthesized by lignin-degrading fungus. Bioresources and Bioprocessing 2016, 3, 8, http://dx.doi.org/10.1186/s40643-016-0083-y.

98. Shahwany, A.W.A.L.; Tawfeeq, H.K.; Hamed, S.E. Antibacterial and Anti-biofilm Activity of Three Phenolic Plant Extracts and Silver Nanoparticles on Staphylococcus aureus and Klebsiella pneumoniae. Biomedicine and Biotechnology 2016, 4, 12-18, https://doi.org/10.12691/bb-4-1-3.

99. Lameire, N. Nephrotoxicity of recent anticancer agents. Clinical Kidney Journal 2014, 7, 11-22, http://dx.doi.org/10.1093/ckj/sft135.

100.Kirtane, A.R.; Kalscheuer, S.M.; Panyam, J. Exploiting nanotechnology to overcome tumor drug resistance: Challenges and opportunities. Adv. Drug Del. Rev. 2013, 65, 1731-1747, http://dx.doi.org/10.1016/j.addr.2013.09.001.

101.Sumitha, S.; Vasanthi, S.; Shalini, S.; Chinni, S.V.; Gopinath, S.C.B.; Kathiresan, S.; Anbu, P.; Ravichandran, V. Durio zibethinus rind extract mediated green synthesis of silver nanoparticles: Characterization and biomedical applications. Pharmacogn. Mag. 2019, 15, 52.

102.Mi, Y.; Shao, Z.; Vang, J.; Kaidar-Person, O.; Wang, A.Z. Application of nanotechnology to cancer radiotherapy. Cancer Nanotechnol. 2016, 7, 11, http://dx.doi.org/10.1186/s12645-016-0024-7.

103.Thao Truong-Dinh, T.; Phuong Ha-Lien, T.; Yichao, W.; Puwang, L.; Lingxue, K. Nanoparticulate Drug Delivery to Colorectal Cancer: Formulation Strategies and Surface Engineering. Curr. Pharm. Des. 2016, 22, 2904-2912, http://dx.doi.org/10.2174/1381612822666160217140932.

104.Khalil, A.T.; Ovais, M.; Ullah, I.; Ali, M.; Shinwari, Z.K.; Hassan, D.; Maaza, M. Sageretia thea (Osbeck.) modulated biosynthesis of $\mathrm{NiO}$ nanoparticles and their in vitro pharmacognostic, antioxidant and cytotoxic potential. Artificial cells, nanomedicine, and biotechnology 2018, 46, 838-852, https://doi.org/10.1080/21691401.2017.1345928.

105.Khalil, A.T.; Ovais, M.; Ullah, I.; Ali, M.; Shinwari, Z.K.; Maaza, M. Physical properties, biological applications and biocompatibility studies on biosynthesized single phase cobalt oxide (Co3O4) nanoparticles via Sageretia thea (Osbeck.). Arabian Journal of Chemistry 2020, 13, 606-619, http://dx.doi.org/10.1016/j.arabjc.2017.07.004.

106. Conde, J.; Doria, G.; Baptista, P. Noble Metal Nanoparticles Applications in Cancer. Journal of Drug Delivery 2012, 2012, 751075, https://doi.org/10.1155/2012/751075.

107.Arvizo, R.R.; Bhattacharyya, S.; Kudgus, R.A.; Giri, K.; Bhattacharya, R.; Mukherjee, P. Intrinsic therapeutic applications of noble metal nanoparticles: past, present and future. Chem. Soc. Rev. 2012, 41, 2943-2970, http://dx.doi.org/10.1039/c2cs15355f.

108.Ovais, M.; Khalil, A.T.; Raza, A.; Khan, M.A.; Ahmad, I.; Islam, N.U.; Saravanan, M.; Ubaid, M.F.; Ali, M.; Shinwari, Z.K. Green synthesis of silver nanoparticles via plant extracts: beginning a new era in cancer theranostics. Nanomedicine 2016, 11, 3157-3177, http://dx.doi.org/10.2217/nnm-2016-0279.

109.Saravanan, M.; Vemu, A.K.; Barik, S.K. Rapid biosynthesis of silver nanoparticles from Bacillus megaterium (NCIM 2326) and their antibacterial activity on multi drug resistant clinical pathogens. Colloids Surf. B. Biointerfaces 2011, 88, 325-331, http://dx.doi.org/10.1016/j.colsurfb.2011.07.009. 
110.Khalil, A.T.; Ovais, M.; Ullah, I.; Ali, M.; Jan, S.A.; Shinwari, Z.K.; Maaza, M. Bioinspired synthesis of pure massicot phase lead oxide nanoparticles and assessment of their biocompatibility, cytotoxicity and in-vitro biological properties. Arabian Journal of Chemistry 2020, 13, 916-931, http://dx.doi.org/10.1016/j.arabjc.2017.08.009.

111.Erathodiyil, N.; Ying, J.Y. Functionalization of Inorganic Nanoparticles for Bioimaging Applications. Acc. Chem. Res. 2011, 44, 925-935, http://dx.doi.org/10.1021/ar2000327.

112.Sperling, R.A.; Parak, W.J. Surface modification, functionalization and bioconjugation of colloidal inorganic nanoparticles. Philosophical Transactions of the Royal Society A: Mathematical, Physical and Engineering Sciences 2010, 368, 1333-1383, https://doi.org/10.1098/rsta.2009.0273.

113. Ricciotti E, FitzGerald GA. Prostaglandins and inflammation. Arterioscler Thromb Vasc Biol 2011; 31(5): 986-1000, http://dx.doi.org/10.1161/ATVBAHA.110.207449.

114.Justin Packia Jacob, S.; Finub, J.S.; Narayanan, A. Synthesis of silver nanoparticles using Piper longum leaf extracts and its cytotoxic activity against Hep-2 cell line. Colloids Surf. B. Biointerfaces 2012, 91, 212-214, http://dx.doi.org/10.1016/j.colsurfb.2011.11.001.

115.Kuppusamy, P.; Yusoff, M.M.; Maniam, G.P.; Govindan, N. Biosynthesis of metallic nanoparticles using plant derivatives and their new avenues in pharmacological applications - An updated report. Saudi Pharmaceutical Journal 2016, 24, 473-484, http://dx.doi.org/10.1016/j.jsps.2014.11.013.

116. Mohamed El-Rafie, H.; Abdel-Aziz Hamed, M. Antioxidant and anti-inflammatory activities of silver nanoparticles biosynthesized from aqueous leaves extracts of four Terminalia species. Advances in Natural Sciences: Nanoscience and Nanotechnology 2014, 5, 035008, https://doi.org/10.1088/2043$6262 / 5 / 3 / 035008$.

117. Kumaran, N.S. biosynthesis of silver nanoparticles using Abutilon indicum (Link): An investigation of antiinflammatory and antioxidant potential against carrageen induced paw edema in rats. Asian Journal of Pharmaceutics (AJP): Free full text articles from Asian J Pharm 2017, 11.

118. Kumaran, N.; Vijayaraj, R.; Swarnakala. Biosynthesis of silver nano particles from leucas aspera (willd.) link and its anti-inflammatory potential against carrageen induced paw edema in rats. International Journal of Pharmaceutical Sciences and Research; 2017, 8, 2588-2593.

119. Chuchawankul, S.; Khorana, N.; Poovorawan, Y. Piperine inhibits cytokine production by human peripheral blood mononuclear cells. Genet. Mol. Res. 2012, 11, 617-627, http://dx.doi.org/10.4238/2012.March.14.5.

120.Mani, A.K.M.; Seethalakshmi, S.; Gopal, V. Evaluation of in-vitro anti-inflammatory activity of silver nanoparticles synthesised using piper nigrum extract. Journal of Nanomedicine \& Nanotechnology 2015, 6 , 1.

121.Baskaran, X.; Vigila, A.V.G.; Parimelazhagan, T.; Muralidhara-Rao, D.; Zhang, S. Biosynthesis, characterization, and evaluation of bioactivities of leaf extract-mediated biocompatible silver nanoparticles from an early tracheophyte, Pteris tripartita Sw. International journal of nanomedicine 2016, 11, 5789, http://dx.doi.org/10.2147/IJN.S108208.

122. Rajakannu S, Shankar S, Perumal S, Subramanian S, Dhakshinamoorthy, G. Biosynthesis of Silver Nanoparticles using Garcinia mangostana Fruit Extract and their Antibacterial, Antioxidant Activity. Int J Curr Microbiol Appl Sci 2015, 4, 944-952.

123.Ahmad, N.; Bhatnagar, S.; Ali, S.S.; Dutta, R. Phytofabrication of bioinduced silver nanoparticles for biomedical applications. Int J Nanomedicine 2015, 10, 7019-7030, https://doi.org/10.2147/ijn.S94479. 